\title{
Using multicurrency cash pooling in the liquidity management of a capital group
}

ABSTRACT: Financial management in a capital group is very important for its growth and operation. Liquidity risk management can be analyzed regarding their static and dynamic dimensions. The process can also be facilitated by cash management products offered by financial institutions. One of the mechanisms influencing the increase in cash management efficiency of a capital group examined in this article is cash pooling, notably multicurrency cash pooling. This type of product is based frequently on the virtual consolidation. Its essence is the consolidation of cash available on the accounts of individual system participants. Using this solution the capital group can manage surpluses and shortages achieving the "economies of scale" (cost reduction and maximization of interest income). Available one the banking services market solutions offer consolidation in USD, EUR, CHF, GBP. The article presents the definition of cash pooling and the essence of its operation. Based on the literature analysis, the article lists types of cash pooling and benefits associated with it. Following on from the solution described, the article presents a model of multicurrency cash pooling in a capital group, including steps necessary to implement it and proposed technical solutions. The solution is described, can be also successfully applied in capital groups of energy sector.

$\triangle$ Corresponding Author: Dawid Ciężki; e-mail: dawid.ciezki@enea.pl

1 Department of Finance of Capital Group, ENEA S.A., Poland; ORCID iD: 0000-0002-5148-0265; e-mail: dawid. ciezki@enea.pl

2 Department of Logistics, Univeristy of Szczecin, Poland; ORCID iD: 0000-0001-5441-0628; e-mail: drozdzwojciech@gmail.com

2019. The Author(s). This is an open-access article distributed under the terms of the Creative Commons Attribution-ShareAlike International License (CC BY-SA 4.0, http://creativecommons.org/licenses/by-sa/4.0/), which permits use, distribution, and reproduction in any medium, provided that the Article is properly cited. 
Using multicurrency consolidation is very useful solution in deposits management for transactions concluded in international commodities exchanges.

KEYWORDS: capital group, cash cooling, liquidity management, liquidity risk, intraday limit

\section{Introduction}

Finance management in a company is an indispensable element of its business activity. Regardless of the type and nature of the business, finance management is always present, and activities related to it are parallel to the main business of the company. Cash management is an important element of finance management. The implementation of suitable cash management mechanisms contributes to the optimization of cash flow and reduces the risk related to the liquidity of finance. In companies that are not linked with each other by any specific structure, cash flow in the form of income and expenditure is managed on a fairly small number of accounts. The situation becomes more complicated when the cash flow management structure encompasses more than one entity. An example of the above is the management of accounts in enterprises comprising a capital group. A particular type of the above is the multinational capital group, a business which involves cash flows denominated in different currencies. To optimize the account management process, companies comprising the group establish links dedicated to the management of their accounts. This is known as cash pooling.

The goal of the article is to present liquidity management issues pertaining to a capital group which uses cash pooling. Apart from the description of the mechanism, the article discusses current issues applicable to the structure of multicurrency cash pooling and the model for its implementation in a capital group.

\section{Liquidity management in a capital group}

Apart from individual companies running their own business, we may distinguish organized structures, such as capital groups. The examined literature provides several definitions of a capital group. A capital group can be defined as 'a set of independent enterprises in terms of their legal structure, which is established to pursue joint economic goals. Those enterprises can be linked by capital and possible contracts to promote their efficient cooperation' (Trocki 2004). According to International Financial Reporting Standards, 'capital group consists of a parent company and its subsidiaries' (IFRS 10). Both definitions assume the existence of two compo- 
nents that determine the sense of establishing a capital group. The first one is the possibility to designate a parent company supervising subsidiaries comprising the same capital group. The second one is the possibility to determine common goals and relations between business units. In business, a common solution involves the development of capital group structures facilitating the expansion of the parent company business. For this purpose, subsidiaries play an auxiliary or complementary role. In certain cases, specific areas of the mainstream parent company activities can be implemented by subsidiaries.

One of key pillars of capital group finance is the liquidity management. Literature defines liquidity as the 'capacity of an enterprise to meet its short-term liabilities in a timely manner'. The loss of liquidity is one of signs of insolvency, which in extreme instances may lead to bankruptcy (Franczak 2016). We should remember, however, that the generation of profit by a company does not immediately mean that the company has a sound financial standing (especially short-term). According to business practice, profit and liquidity do not have to be present in parallel (Sałdyka 2011).

A relevant cash balance plays an important role in maintaining liquidity in capital group. Reserves, including those for contingencies, help enterprises to meet their liabilities and continue their business in an uninterrupted manner.

Liquidity can be analyzed using static and dynamic methods (Sierpińska and Wędzki 1999). According to static methods, liquidity can be assessed based on the following:

a. Cash flow in a given period, and

b. Cash and short-term liabilities in the balance sheet.

The static analysis of liquidity may use such indicators as:

$\downarrow$ current liquidity,

$\downarrow$ current ratio,

$\uparrow$ treasury ratio.

Considering resources specified in the balance sheet, the static liquidity analysis does not provide a complete picture. A financial report developed for a specific reporting date makes the liquidity analysis, based on data available, valid for that date only.

The second liquidity analysis method is based on dynamic factors. Dynamic methods as such are based on financial results recorded in the cash flow statement as a means to assess the financial standing of an enterprise (Cicirko 2010). Cash flow analysis involves defining the ratio between income and expenditure in three business areas: operation, investment and finance. It enables to determine the generation of cash or shortages while indicating their sources. In business practice, we may distinguish two approaches to the development of a cash flow statement, namely indirect and direct methods.

Appropriate liquidity management determines added values for the company in two dimensions:

$\downarrow$ financial: maintenance of liquidity reduces the additional cost of engaging liquidity support mechanisms. Liquidity can be ensured, inter alia, by maintaining a balance between sources of finance, working capital management, suitable policy towards liabilities, efficient collection of receivables, surplus management, etc. 
business - liquidity translates into a positive image of an enterprise or a capital group by suppliers, reduces the risk of losing contracts and shrinking profit margins.

Liquidity management can be supported by banking products available on the market, which facilitates cash flow planning, monitoring and management. The above-mentioned solutions, services and products are based on cash management, including cash pooling (PEKAO).

\section{Idea of cash pooling}

Liquidity management in a capital group necessitates the analysis of the cash flow structure within the group and payments made to external entities. In the case of individual enterprises, liquidity and liquidity risk management is considered from the point of view of a single company only, whereas in capital groups some companies may have a shortage and others a surplus of cash. Therefore, it is crucial to apply a management method to reduce the need to resort to external sources of finance. The literature points to two issues of cash management, namely cash flow velocity and the efficiency of its management (Sierpińska and Wędzki 2002). Among other things, cash pooling is a product that improves the efficacy of finance management in a capital group.

Cash pooling allows balances on separate accounts to be managed collectively. It also involves coordinated liquidity and related risk management, as well as the optimization of current finance operations (Zawal-Kubiak 2004).

The literature includes various definitions of cash pooling. However, it should be emphasized that none of them have been commonly accepted (Remlein 2014). Below you can find the most frequently used definitions of cash pooling:

$\checkmark$ cash pooling is a process of moving cash between accounts of participating entities and the main account of the group of entities (Grabowska 2012).

$\downarrow$ cash pooling is a specialist comprehensive banking service tailored for capital groups, which enables to optimize the management of joint current liquidity while ensuring optimized interest (Dąbrowska 2010).

$\checkmark$ cash pooling is an advanced instrument that optimizes cash flows in enterprises belonging to the same capital group or having a multi-level organizational structure (Panfil 2008).

In business practice, cash pooling is basically the collective management of several accounts. To a large extent, accounts of participants in the cash pool are consolidated to form a collective account. Since it is possible to set limits on individual accounts within the structure and the consolidation of cash flows at the level of the consolidated account, shortages on individual accounts can be compensated by financial surpluses generated by other parties to the structure. In the case of companies running their business using more than one currency, it is also possible to consolidate currency accounts. Parameters used for the configuration of the cash pooling system should be adjusted on a case to case basis while taking links between parties and relevant laws in countries involved into account. 


\section{Cash pooling systems}

We can distinguish various forms of cash pooling among a bank's cash management offerings. The main feature is the transfer of funds between the consolidated account and individual accounts. As regards different types of consolidation, we can have real and virtual cash pooling:

a) real cash pooling

The real cash pooling mechanism involves the automatic consolidation of funds in individual accounts by a bank providing the solution at the end of each settlement day. According to the contract, the bank is responsible for the redistribution of funds between accounts, the calculation of interest and settling of previously calculated interests by crediting and debiting individual accounts within the structure. Under the real cash pooling, cash can be consolidated using one of the following methods:

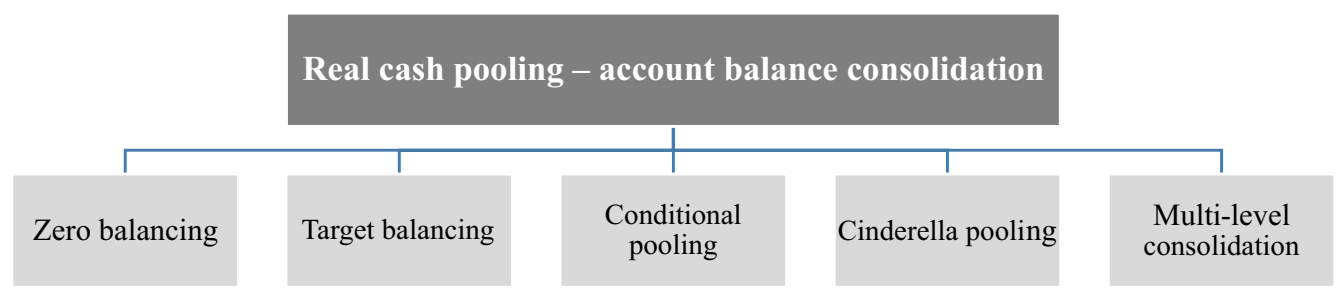

Fig. 1. Account balance consolidation under real cash pooling Source: author's own material based on Orliński 2013

Rys. 1. Konsolidacja sald rachunków w ramach cash poolingu rzeczywistego

In practice, the method which is the most frequently applied involves the transfer by the settlement agent (bank) of funds from individual accounts to the consolidated account of the Cash Pool Leader (CPL) at the end of each settlement day. Simultaneously, information is provided about negative balances on individual accounts. The balance at the consolidated account is calculated as a sum total of positive and negative balances of individual accounts. The zero balancing goal is set for negative individual balances, whereas the surplus remains at the CPL account. In case the CPL account shows a negative balance, the bank establishes an overdraft on the current account. The agent calculates interest on individual balances, both positive and negative. The following day, cash from the consolidated account is transferred to individual accounts up to the level of the balance on the previous day. In the case of negative balances, an individual balance maintains its negative value. In parallel to the transfer, interest is either credited or debited at individual accounts of participants.

Other above-mentioned methods help to develop structures that enable to leave a positive balance on individual accounts at the end of the settlement day (target balancing), reducing the 
need to finance subsidiaries (conditional pooling) or use surplus to balance shortages (Cinderella pooling) (Orliński 2013).

b) Virtual cash pooling

The notional cash pooling is based on optimization of interest related to individual accounts in cash pooling. The virtual cash pooling does not lead to the physical pooling of cash from individual accounts. In principle, the method involves the calculation of interest on individual balances. In practice, two types of notional cash pooling can be found on the market.

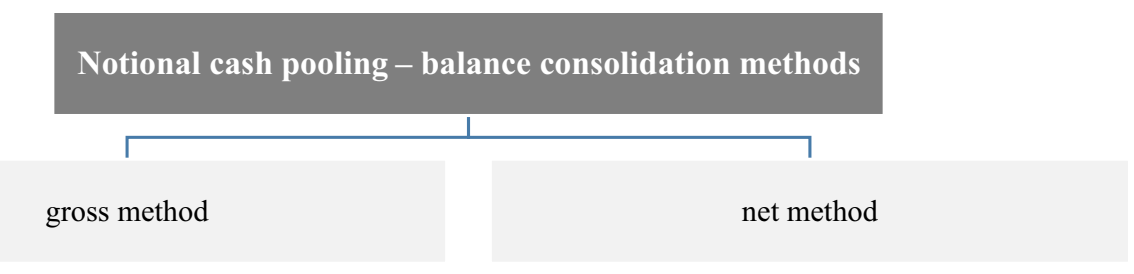

Fig. 2. Notional cash pooling consolidation methods Source: author's own material

Rys. 2. Metody konsolidacji środków pieniężnych w cash poolingu wirtualnym

The gross method involves the calculation and crediting of interest for each participant's account separately. After calculating and recording interest on positive and negative balances, calculating of the balance for the group of accounts and calculating of interest on the consolidated balance, the resulting amount, which corresponds to the difference between interest on participants' accounts and the interest on the notional consolidated account, is either credited or debited.

The net method involves determining the consolidated balance for the group, calculation of interest and crediting it to the consolidated account (Grzywacz 2008).

Yet another division of cash pooling focuses on a number of currencies:

a) single-currency cash pooling

b) multicurrency cash pooling

In the case of a single-currency cash pooling, balancing is provided in one currency and all accounts are usually held in one country, whereas in the case of a multicurrency cash pooling, apart from settlements in a number of different currencies, accounts are run by branches of the same agent in various countries.

In its further part, the article focuses on multicurrency cash polling. 


\section{Benefits of cash pooling in a capital group}

As indicated in the former part of the article, cash pooling is a product designed to enhance cash management efficiency. From the economic point of view, the improved efficiency is understood as reducing the cost of external financing and boosting revenue due to the management of the surplus in a capital group. On the one hand, the balancing of shortages encountered by participants generating negative results with the surplus of other participants helps to avoid the need to resort to loan funding and interest cost otherwise incurred by the capital group. On the other hand, the cash pooling at the consolidated account managed by the pool leader enables to make deposits of negotiable interest at higher rates of return due to a larger cash pool in question. In the long-term perspective, surplus management enables the use of various methods and products that generate a higher return than fixed term standard deposits. Apart from fix term deposits, overnight facilities can also play an important role. This is because capital groups enjoy a better position vis-a-vis banks that enables them to negotiate better interest rates for their consolidated accounts if compared with individual partner accounts (Remlein 2014). Apart from financial benefits, cash pooling helps to improve the liquidity of the capital group and significantly reduces the risk of insolvency. The internal financing mechanism based on individual limits provides more flexibility and accessibility than debt financing that requires, inter alia, a number of loan arrangement in the part of the financial institution.

While analyzing the benefits of cash pooling, some of the major steps leading towards its implementation are worth mentioning. Certain activities presented below involve an additional cost one needs to be prepared to incur during the cash pooling project.

TABLE 1. Benefits and problems during the implementation of cash pooling in the capital group

TABELA 1. Korzyści oraz problemy towarzyszące wdrożeniu cash poolingu w grupie kapitałowej

\begin{tabular}{|c|c|}
\hline Cash pooling benefits & Cash pooling challenges during implementation \\
\hline $\begin{array}{l}\text { 1. Reduced need to resort to debt financing - } \\
\text { optimized cost of interests. } \\
\text { 2. Improved efficiency of surplus cash management } \\
\text { - optimized interest revenue. } \\
\text { 3. Enhanced cash management. } \\
\text { 4. Better control over liquidity management and the } \\
\text { management of liquidity risk from the point of view } \\
\text { of the owner - pool leader. } \\
\text { 5. Reduced risk of capital group liquidity loss. } \\
\text { 6. Possibility to shift debt limits from current ope- } \\
\text { ration to long-term external financing. } \\
\text { 7. Improved management of cash shortages and } \\
\text { shorter time needed to secure financing for cash } \\
\text { pooling participant. }\end{array}$ & $\begin{array}{l}\text { 1. Need to commission expert opinions during the cash } \\
\text { pooling implementation project. } \\
2 \text {. Need to incur additional cost, adjustment of finance and } \\
\text { accounting systems to handle cash pooling (one-off during } \\
\text { implementation). } \\
\text { 3. Need to establish interest rates within the group to take into } \\
\text { account the market situation. } \\
\text { 4. In case of a negative balance in the structure of cash } \\
\text { pooling, there is usually a need to contract a current account } \\
\text { overdraft facility by a pool leader. } \\
5 \text {. In the case of a multicurrency cash pooling, parties need } \\
\text { to deal with different tax legislation in particular countries of } \\
\text { business operation. } \\
6 \text {. Additional resources needed to implement and run the cash } \\
\text { pooling structure. }\end{array}$ \\
\hline
\end{tabular}

Source: own materials. 


\section{Implementation of multicurrency cash pooling in a capital group}

As discussed in the first part of the article, cash pooling may significantly improve the efficiency of finance management in a capital group. Therefore, the final chapter of the article is going to focus on a model implementation of multicurrency cash pooling in a capital group operating in more than one country.

Currently capital groups that intend to expand onto foreign markets need to organize the operation of their subsidiaries and the management of their strategic resources, including finance. Since companies operate in several countries having different currencies, their cash is kept at different accounts run by banks in particular countries. Financial operations denominated in more than one currency results in a versatile structure of cash and the need to maintain liquidity for each currency separately. Modern products offered by banks, e.g. multicurrency cash pooling come as a solution to the problem. Multicurrency cash pooling is the extension of single-currency cash pooling by establishing accounts in other currencies in divisions of that bank abroad. The new solution has a lot in common with the traditional domestic cash pooling. Like in the traditional cash pooling, a new structure is actually established together with a consolidated pool leader account. Other similar features include the reversible or irreversible mode of operation. What differentiates single-currency domestic structures from multicurrency ones is the possibility of having settlements in a number of currencies.

\section{Model implementation of multicurrency cash pooling in a capital group}

\section{A. Main stakeholder:}

A capital group operating in Poland and expanding on foreign markets in EU member states, where transactions are handled in Euro, USD, HUF.

\section{B. Key objectives of multicurrency cash pooling:}

$\downarrow$ Capital group already uses cash pooling in the domestic currency through an international bank having its branches in France (Euroland), the United States and Hungary.

$\downarrow$ Currencies used in capital group cash flows: EUR, USD, HUF.

$\downarrow$ Real consolidation.

४ The main currency for the multicurrency cash pooling is EUR.

$\checkmark$ External financing (credit, overdraft) to be provided by the pool leader, or the parent company.

$\downarrow$ Liquidity limits set for companies operating abroad.

- Interest is calculated on positive and negative balance at participants' accounts.

$\checkmark$ Pool leader account is to be set in Poland.

\section{Key issues to be decided during project implementation:}

- Civil law tax issues, transfer pricing, thin capitalization, and withholding tax.

$\downarrow$ Laws applicable in each country where the group has a currency account. 
$\checkmark$ Need to solicit an interpretation of the tax regulations.

$\checkmark$ Need to determine the legal title for cash pool transfers.

\section{Multicurrency cash pooling implementation:}

$\downarrow \quad$ Draft structure of multicurrency cash pooling taking subsidiaries, their accounts, currencies, settlement model, and type of limits into consideration.

- Analysis of legal and taxation issues.

Stage completion: guidelines for multicurrency cash pooling and the legal and taxation framework. $\uparrow$ Negotiation of banking documentation.

\ Preparation of internal documents.

४ Technical configuration of multicurrency cash pooling (systems, accounts, reporting).

\ Limits and settlement terms.

$\downarrow$ Mechanisms of transfer pricing and withholding tax.

Stage completion: preparation of technical issues, documents and processes. $\checkmark$ Closing contracts with the bank.

$\downarrow$ Cash pooling operation.

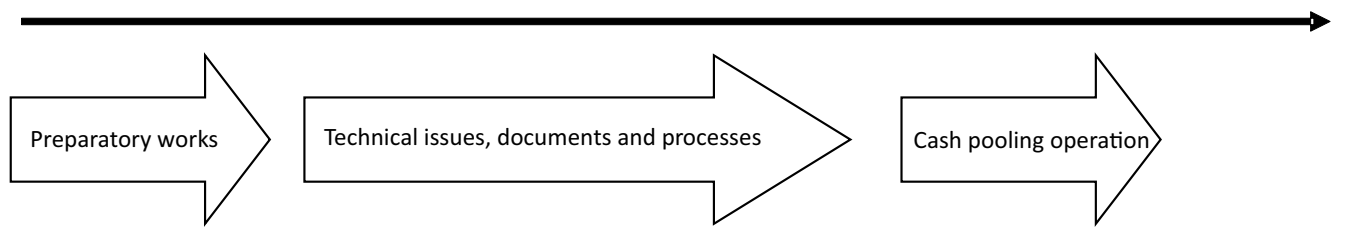

Fig. 3. Multicurrency cash pooling implementation Source: author's materials based on (PKO BP)

Rys. 3. Schemat wdrożenia cash poolingu wielowalutowego

\section{E. Types of limits in multicurrency cash pooling}

In the case of the multicurrency cash pooling, limits set are identical to the domestic singlecurrency cash pooling, and they enable the pool leader to control cash flow between particular accounts. The flow chart below shows an example of limit configuration. 


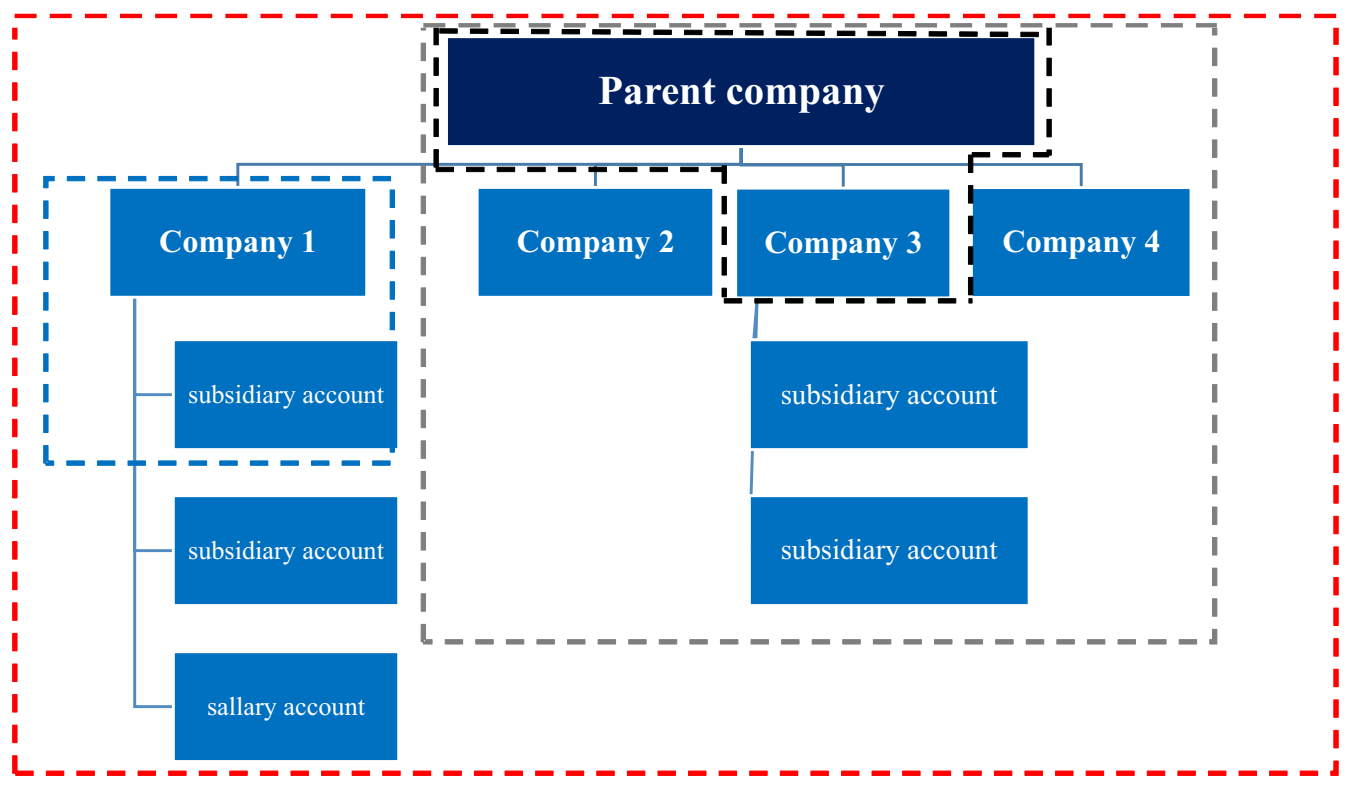

\begin{tabular}{|l|l|}
\hline Liquid umbrella limit & $\begin{array}{l}\text { defines the balance at a participant's account and is the sum total of balances cove- } \\
\text { red with the umbrella limit. }\end{array}$ \\
\hline Transaction limit & defines the top amount that can be incurred in a given period (day, month, etc.). \\
\hline Umbrella limit & $\begin{array}{l}\text { defines the accessible balance of the participant based on the sum total of individual } \\
\text { balances on the accounts covered by the umbrella limit. }\end{array}$ \\
\hline Sublimit & defines the maximum cash flow. \\
\hline
\end{tabular}

Fig. 4. Multicurrency cash pooling limits Source: Author's materials based on (PKO BP)

Rys. 4. Limity w cash poolingu wielowalutowym

\section{Summary}

Properly structured and monitored liquidity management in a capital group facilitates the payment of liabilities and prevents insolvency risk. Liquidity management in a capital group can be analyzed in its static or dynamic dimensions and is supported by cash management products offered by banks.

Cash pooling is one of tools used by capital groups to manage their liquidity and liquidity risk. Considering the structure of links between companies that are members of the capital group, the implementation of the solution to manage a series of accounts leads to improved efficiency 
in the capital group finance management. Cash pooling involves the consolidation of participants' accounts into a consolidated account managed by the agent which plays the role of the pool leader. The consolidation is automatic and it is designed to cover shortages of cash in some participants with a surplus from other participants.

Depending on the actual needs and the nature of the business, cash pooling used by a capital group can be real or notional. Within particular structures it is possible to use different types of cash consolidation. Cash pooling can be implemented using a single domestic currency, but is can also be extended to cover multiple currencies.

Apart from the improved liquidity of the capital group, cash pooling leads to fewer costs from external loans. Thus, it reduces the need to contract and use working capital loans. The cash pooling mechanism helps to manage surpluses in the entire capital group, which translates into specific benefits (interest on larger deposits etc.). While deciding to implement cash pooling, a capital group should take certain additional burdens into account (labor, costs), and in the case of the multicurrency cash pooling, also issues related to the need to solicit taxation and other law interpretations.

In summary, objectives and the model of the multicurrency cash pooling presented in the article have confirmed an added value generated by the implementation of the tool to manage liquidity in a capital group. Cost to be incurred while implementing the solution does not exceed possible benefits, which bodes well for the development of those products in the future.

\section{References}

CICIRKO, T. 2010. Foundations of liquidity management in a company (Podstawy zarzadzania plynnościa finansowa przedsiębiorstwa). Oficyna Wydawnicza, Warsaw School of Economics, Warsaw (in Polish).

DĄBROWSKA, M. 2010. Cash pool service - efficient joint liquidity management in a capital group. [In:] Active company liquidity management (Ustuga cash pool - efektywne zarzadzanie wspólna plynnościa finansowa w grupie kapitałowej. [W:] Aktywne zarzadzanie plynnościa finansowa przedsiębiorstwa), ed. K. Kreczmańska-Gigol, Difin, Warsaw (in Polish).

FRANCZAK, I. 2016. Cash Pooling as a modern liquidity management of a capital group (Cash Pooling jako nowoczesna strategia zarządzania plynnościa finansowa grupy kapitałowej). ZN WSH Zarządzanie 2016 (3), p. 71-80, Częstochowa.

GŁUCHOWSKI, J. 2001. Lexicon of finance (Leksykon finansów). Warsaw: PWE (in Polish).

GRABOWSKA, M. 2012. Liquidity management in companies (Zarządzanie plynnościa finansowa przedsiębiorstw). Warsaw: CeDeWu.pl Wydawnictwa Fachowe (in Polish).

GRZYWACZ, J. and LIPSKI, M. 2008. Cash pooling as an instrument of efficient cash management in a company. (Cash pooling jako instrument efektywnego zarządzania środkami pieniężnymi w przedsiębiorstwie). Studia i Prace Kolegium Zarządzania i Finansów No. 89, Warsaw School of Economics, Warsaw (in Polish).

MSSF 10. International Financial Reporting Standard 10 Consolidated financial statements.

ORLIŃSKI, B. 2013. The use of "cash pooling" in capital groups comprising small and medium-sized enterprises (Wykorzystanie "cash poolingu” w grupach kapitalowych malych i średnich przedsiębiorstw), Ekonomiczne Problemy Ustug No. 102. 
PEKAO. [Online] https://www.pekao.com.pl/corporate_clients/cash_management/?s,main,language=EN, [Accessed: 2018-11-15].

PKO BP. Szumielewicz W. and Firląg A. 2018. Hit in liquidity management of a capital group (Hit zarzadzania płynnościa w grupie kapitałowej). Prezentacja z Konferencji PCTA, Toruń, 19-21 April 2018 (in Polish).

REMLEIN, M. 2014. Cash pooling as an cash management instrument in a capital group (Cash pooling jako instrument zarządzania środkami pieniężnymi w grupie kapitałowej). Scientific Journals of Szczecin University No. 830, Finance, Financial Markets, Insurance No. 70/2014 (in Polish).

SAŁDYKA, P. 2011. Cash flow account in practice. Drafting techniques (Rachunek przepływów pieniężnych w praktyce. Techniki sporzadzania). Wrocław: UNIMEX (in Polish).

SIERPIŃSKA, M. and WĘDZKI, D. 1999. Liquidity management in a company (Zarządzanie plynnościa finansowa w przedsiębiorstwie). Warsaw: PWN (in Polish).

Panfil 2008. Financing of company development. Case Studies (Finansowanie rozwoju przedsiębiorstwa. Studia przypadków), ed. M. Panfil, Difin, Warsaw (in Polish).

TrockI, M. 2004. Capital groups. Establishment and operation (Grupy Kapitalowe. Tworzenie i funkcjonowanie). Warsaw: PWN (in Polish).

ZAWAL-KUBIAK, H. 2004. Cash pooling - consequences for income tax (Cash pooling - skutki w podatku dochodowym), Przeglad Podatkowy No. 2 (in Polish).

\section{Wykorzystanie cash poolingu wielowalutowego w zarządzaniu płynnością grupy kapitałowej}

\section{Streszczenie}

Zarządzanie finansami w grupie kapitałowej pełni istotną rolę dla jej rozwoju oraz działalności. Jednym $\mathrm{z}$ istotnych elementów zarządzania finansami jest zarządzanie ryzykiem płynności. Proces ten może być analizowany w wymiarze statycznym oraz dynamicznym, jak również wspomagany oferowanymi przez instytucje finansowe produktami z grupy cash management. Jednym z mechanizmów mających wpływ na wzrost efektywności zarządzania środkami pieniężnymi w grupie kapitałowej jest cash pooling, w ramach którego wyróżniamy m.in. cash pooling wielowalutowy. Produkt wykorzystuje najczęściej konsolidację wirtualną. Jego istotą jest konsolidacja środków pieniężnych dostępnych na rachunkach poszczególnych uczestników systemu. Dzięki wykorzystywanemu rozwiązaniu grupa kapitałowa może wspólnie zarządzać nadwyżkami oraz niedoborami osiągając ,efekt skali”. Dostępne na rynku usług bankowych rozwiązania oferują konsolidację walut takich jak USD, EUR, CHF, GBP. Celem artykułu jest przedstawienie istoty zarządzania płynnością $\mathrm{w}$ grupie kapitałowej z wykorzystaniem cash poolingu wielowalutowego. $\mathrm{W}$ artykule przedstawiono definicję cash poolingu oraz istotę jego funkcjonowania. Na podstawie analizy literaturowej wskazano rodzaje oraz korzyści związane z jego wdrożeniem. Odnosząc się do opisanego w artykule rozwiązania przedstawiono model wdrożenia cash poolingu wielowalutowego w grupie kapitałowej, 
określając zakres prac niezbędny do przeprowadzenia wdrożenia oraz propozycję rozwiązań technicznych. Opisywane rozwiązanie może być również zastosowane z powodzeniem w grupach kapitałowych sektora energetycznego. Wykorzystanie konsolidacji w wielu walutach pomaga rozwiązać problem związany z zarządzaniem depozytami w związku z transakcjami zawieranymi na międzynarodowych giełdach towarowych.

SŁOWA KLUCZOWE: grupa kapitałowa, cash pooling, zarządzanie płynnością, ryzyko płynności, limit intraday 
